\title{
THE ESTABLISHMENT OF EXPERIMENTAL GREEN ROOFS
}

\author{
Věra Hubačíková ${ }^{1}$, Lenka Filipová, Petr Pelikán² \\ ${ }^{1}$ Department of Applied and Landscape Ecology, Faculty of Agronomy, Mendel University in Brno, Zemědělská 1, \\ 61300 Brno, Czech Republic \\ ${ }^{2}$ Department of Landscape Management, Faculty of Forestry and Wood Technology, Mendel University in Brno, \\ Zemědělská 1, 61300 Brno, Czech Republic
}

\begin{abstract}
HUBAČÍKOVÁVĚRA,FILIPOVÁLENKA,PELIKÁNPETR.2018.TheEstablishmentofExperimental Green Roofs. Acta Universitatis Agriculturae et Silviculturae Mendelianae Brunensis, 66(1): 0043-0048.

The aim of the work was establishment of research green roofs on Mendel University in Brno. The experimental green roofs were established in August 2015 and it is based on current issues of rainwater management and the quality of storm water launched into recipients or sewage system. There is a valid legislation addressing the management of rainwater in environment-decree no. 268/2009, Coll., and decree no. 269/2009, Coll. Four experimental plots were created and placed in Mendel University Campus. It was hypothesized that different types of experimental plots will result in different amount of retained water and in different quality of water runoff. Resulting hypotheses proved statistically significant difference between the height of rainfall and runoff height on individual types of green roofs. In addition, it was shown that the different types of roofs prove statistically significant difference in the ability to reduce runoff (retention efficiency).
\end{abstract}

Keywords: experiment, green roof, water retention, storm water runoff, hypothesis

\section{INTRODUCTION}

Rainwater management is currently much discussed topic in the Czech Republic. People constructing their houses regularly meet with the requirement of the building authority for disposal of rain water from the site of construction. Since 2009, valid legislation addresses the management of rainwater in environment. In particular, the decree implementing the Building Act no. 268/2009 Collections, as amended, and Decree of the Ministry for Regional Development no. 269/2009 Coll.

Decree no. 268/2009 Coll., \$6, section (4) states: "Buildings of which flow off the surface water resulting from the impact of atmospheric precipitation (hereinafter referred to as "rain water"), must ensure their removal, unless rainwater is retained for future use. The pollution of these waters by harmful substances or their excessive amounts are handled by appropriate technical remedies. Removal of rain water is provided by infiltration preferably. If it is not possible, it is ensured their removal into surface water; unless it can be drained separately, it is removed by the uniform sewers."

So far, it is usual that the construction joined the storm sewer system that rainwater runoff drained into streams. However, more and more cities solves the problem of the storm sewer capacity. Therefore, given the huge amount of unused roof area (Dunnett and Kingsbury 2004), green roofs may be one possible alternative way of dealing with rainwater runoff. Moreover, the creation of more green areas is also an answer to the recent calls for a more ecological and greener urbanization (White 2002). However, the impact of green roofs on the storm water quality remains a topic of concert to city planners (Vijayaraghavan et al., 2012). Current studies point out that green roofs may be a sink for some pollutants (Vijayaraghavan and Joshi 2014; Gregoire, Clausen 2011)

Green roofs basically consist of a vegetation layer, a substrate layer (where water is retained and in which the vegetation is anchored) and a drainage layer (to evacuate excess water) (Mentens et al., 2003). 
In the terminology of design and architectural solutions for flat roofs have long since enshrined the concept of "green roof" like a roof covered with vegetation.

Green Roofing is divided into three different types, depending on use, construction factors and the method used to carry out the work. These play a critical part in determining both the plant types which are selected and how the vegetation will look. Green roofs can be: (a) intensive, (b) simple intensive or (c) extensive. Each of these types covers a variety of forms of cultivation, with seamless transition and site-specific differentiation (Losken et al., 2008).

Small capacity of substrate (up to $150 \mathrm{~mm}$ of depth) in extensive green roofs offers conditions for perennials, alpine plants and xerophilous plants (such as Sedum sp.) that can withstand extreme conditions of heat, drought and frost. Due to the fact, this type of green roofs is suitable for sloping roofs (up to $45^{\circ}$ ) (Mentens et al., 2006). On the other hand, intensive green roof is implemented in structures having a resistance of up to $1000 \mathrm{~kg} \cdot \mathrm{m}^{-2}$, so it is possible to use soil to a thickness of 1-1.3 metres, which is suitable for forming and using garden flowers, shrubs and low trees. Intensive green roofs are more demanding in terms of maintenance (Losken et al., 2008).

The main advantages of green roofs include decongesting the sewer system and slowing rainwater runoff, or production of oxygen and carbon dioxide saturation as well as absorption of pollutants from the air, and, ultimately, helping to increase biodiversity in urban environments. As a disadvantage could be considered structural complexity (especially the emphasis on the waterproofing layer) and the need for statically reinforced load-bearing structure of the building.

The experiment described below deals with current issues of rainwater management and the quality of storm water launched into recipients or sewage system. The size of built-up areas in the landscape is constantly growing, thus increasing the quantity of rainwater drained into sewage networks already designed which capacity is not enough. Therefore, it is necessary to look for alternatives in the storm water runoff management. Due to their structural arrangement, green roofs provide a suitable way of solving this issue, especially in industrial areas and technical parks in which flat-roofed buildings dominate.

The objective of the experiment was to verify the possibility of retention of rainwater directly on the roof and reduce the total amount of runoff using green roofs. The aim of the statistical data processing was to answer the following questions (i.e., testing of properly formulated statistical hypotheses).

a) The recognition whether there is a statistically significant difference between the rainfall height and the height of runoff from the constructed types of green roofs, so whether the proposed types of roofs are able to significantly reduce direct runoff. b) And, if so, whether there are proven statistically significant differences in the ability of rainwater retention between different types of green roofs.

\section{MATERIAL AND METHODS}

Four simulated roof platforms with overall dimensions of $2 \times 8 \mathrm{~m}$ (Fig. 2) were constructed on Mendel University Campus in Brno (Zemedelska street, Brno; GPS: 49.2098817N, 16.6133425E). However, since there was not an environmentally controlled room under the platform, heat flux through the roof can be discounted. Roof platforms were divided into four equal sections measuring $2 \times 2 \mathrm{~m}$ using wood dividers that were also covered with the waterproofing membrane. There are four variants of experimental plots to determine differences in water filtration:

A. extensive green roof with following layers: protective water-storage fabric (Optigreen type RMS 300), drainage nep film (Optigreen type FKD 40), filtering fabric (Optigreen type 105), extensive substrate (Optigreen type E, $100 \mathrm{~mm}$ of depth; composition below), vegetation cover (list of species named below)

B. extensive green roof with following layers: protective water-storage fabric (Optigreen type RMS 300), drainage nep film (Optigreen type FKD 40), filtering fabric (Optigreen type 105), extensive substrate (extensive "Czech" substrate, $100 \mathrm{~mm}$ of depth; composition named below), vegetation cover

C. extensive green roof with following layers: protective water-storage fabric (Optigreen type RMS 300), hydrophilic panel (ISOVER hydrophilic vegetation panel Cultilene), extensive substrate (Optigreen type E, $50 \mathrm{~mm}$ of depth), vegetation cover

D. semi-intensive green roof with following layers: protective water-storage fabric (Optigreen type RMS 300), hydrophilic panel (ISOVER hydrophilic vegetation panel Cultilene), extensive substrate (Optigreen type E, $150 \mathrm{~mm}$ of depth), vegetation cover

Scheme of typical green roof is illustrated on Fig. 4. Plots are made of wood standing on concrete permanent formworks. Slope of roofs is $5 \%$. Hydrophilic vegetation panel is used to determine a function of water retention and filtration so there is no need to use a drainage nep film and filtring fabric in these plots (ISOVER, 2015). Exensive substrate Optigreen type E has $\mathrm{pH}$ 6.0-8.5 and consist of expanded shale, lava, pumice-stone, keramzit (expanded clay), crushed brick and green compost. Extensive "Czech" substrate has pH 6.2-6.8 and consist of crushed Liapor, crushed brick, cinder, peat and PG mix 14-16-18 (fertilizer). Vegetation consist of Achillea millefolium, Allium schoenoprasum, Anthemis tinctoria, Aster amellus, Campanula rotundifolia, Centaura scabiosa, Chrysanthemum leucanthemum, Dianthus carthusianorum, Dianthus deltoides, Galium verum, Geranium robentianum, Hieracium aurantiacum, Linaria vulgaris, Organum vulgare, Petrorhagia saxifrage, 


\begin{tabular}{|c|c|c|c|c|}
\hline sample & A & B & C & D \\
\hline Vegetation cover & \multicolumn{4}{|c|}{ Optigreen type $\mathrm{E}$ (xerophilic herbs and grasses) } \\
\hline substrate & $\begin{array}{l}\text { Optigreen } \\
\text { "Czech“ } \\
\text { substrate }\end{array}$ & \multicolumn{3}{|c|}{ Optigreen type E } \\
\hline Depth of substrate & $100 \mathrm{~mm}$ & $100 \mathrm{~mm}$ & $20 \mathrm{~mm}$ & $150 \mathrm{~mm}$ \\
\hline Filtration fabric & \multicolumn{2}{|c|}{ Optigreen type 105} & \multirow{2}{*}{\multicolumn{2}{|c|}{$\begin{array}{l}\text { Isover hydrophilic vegetation } \\
\text { panels Cultilene }\end{array}$}} \\
\hline Drainage nep film & Optigreen & FKD 40 & & \\
\hline $\begin{array}{l}\text { Protective } \\
\text { water-storage fabric }\end{array}$ & \multicolumn{4}{|c|}{ Optigreen type RMS 300} \\
\hline
\end{tabular}

1: Materials used in experimental plots source: authors

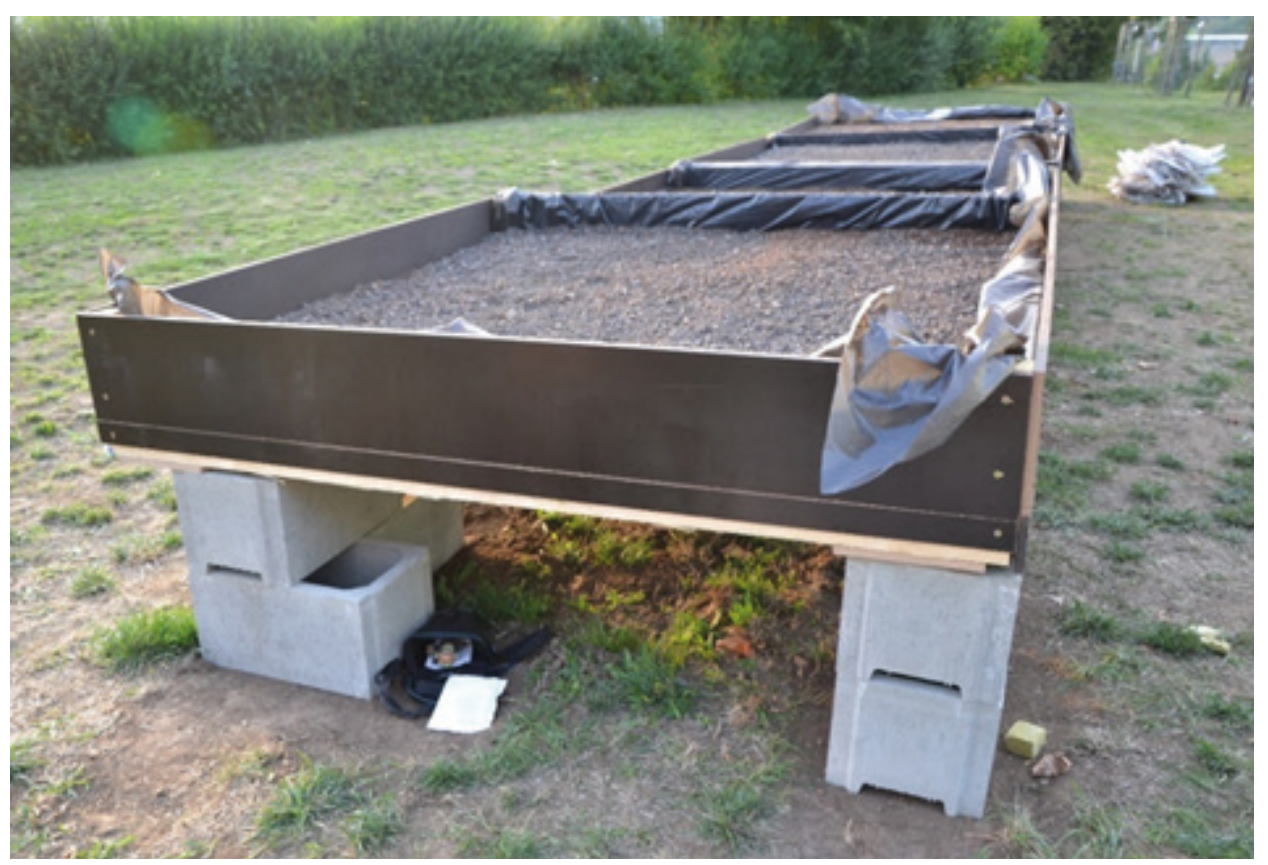

2: Experimental plots of green roofs in Mendel University Campus, photographed on a day of establishment, vegetation is in a phase of sowing, due to this substrate layer is visible August 2015; photo: by author)
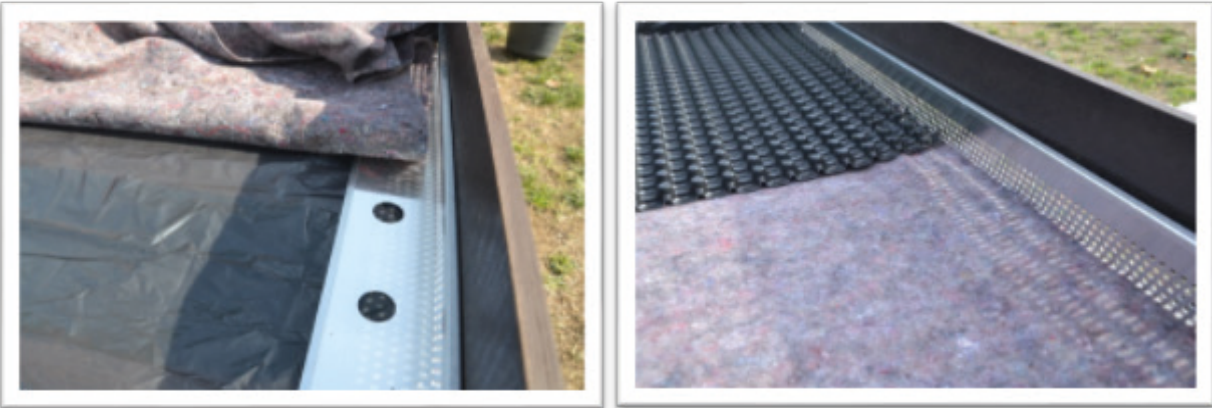

3: Detail of green rooflayers - protective water storage fabric (on the left) and drainage nep film (on the right); photographed on a day of establishment August 2015; photo: by author 


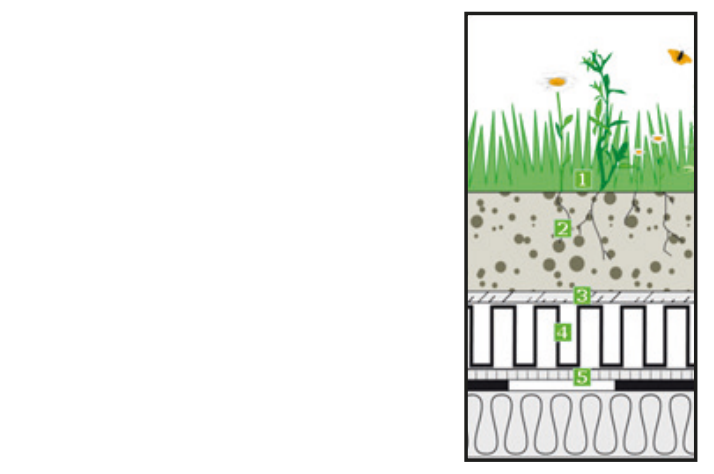

4: Scheme of green rooflayers-(1) vegetation cover, (2) substrate (3) filtration fabric (4) drainage nep film

(5) protective water-storage fabric (www.optigreen.cz) source: authors

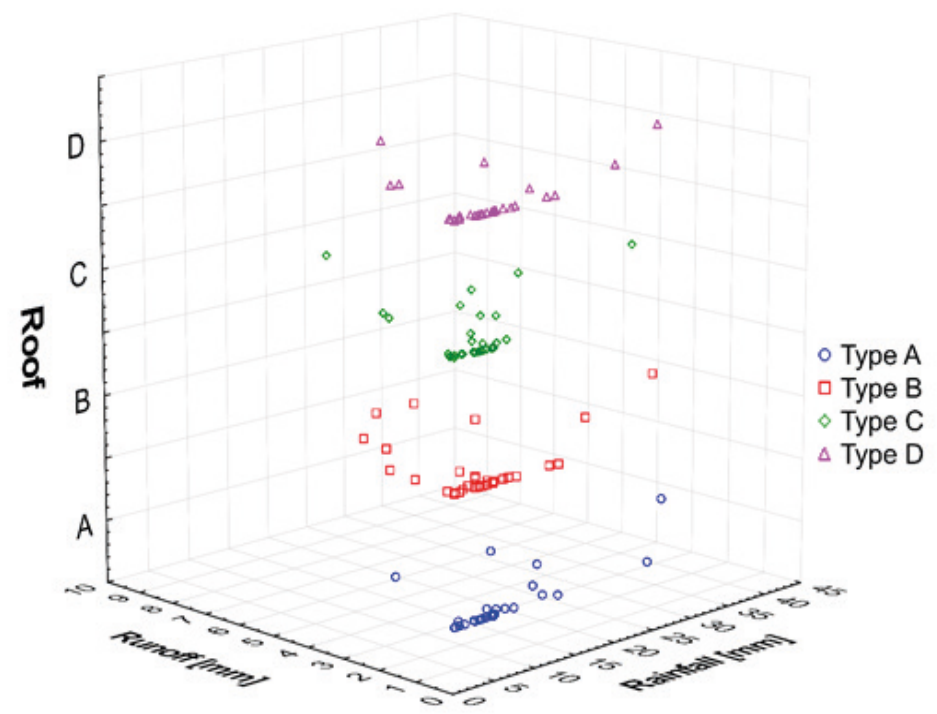

5: The measured data source: authors

Potentilla argentea, Prunella grandiflora, Prunella vulgaris, Sanguisorba minor, Saponaria ocymoides, Saponaria officinalis, Sedum album, Sedum reflexum, Silene nutans, Thymus pulegioides, Thymus serpyllum, Festuca tenuifolia, Festuca ovina vulgaris, Melica ciliate, and Vulpia myuros (Ekrost, 2015).

In the period 2016/6-2016/12 were measured the retention of storm water to the individual green roof. After each precipitation were checked subtracted the volume of water flow on each roof. Measured runoff data for all four types of green roofs related to rainfall events are shown in Fig 5. For the purposes of determining the retained water in green roofs data from meteorological stations located in the campus of the University and the Institute of Geonics of the Czech Academy of Sciences, based on Schodová street in Brno, will be used.

Exploratory data analysis (EDA) was focused on the general characteristics of data and in particular to determine whether the measured values of precipitation and runoff meet the criteria for using parametric or non-parametric tests.
For quantitative datasets ( $\mathrm{n}>25$ ) with a normal distribution with the same variance can be used parametric tests. Non-parametric tests are suitable for the other datasets, although, generally have less strength-the worse ability to reject the null hypothesis, if not correct (Meloun and Militký, 2004). Based on the results of EDA, the appropriate test was selected to verify the hypotheses and the testing criteria were calculated for data on the specified level of statistical significance. If we want to compare two variables measured in the same sample we would customarily use the t-test for dependent samples. Nonparametric alternatives to this test are the Sign test or Wilcoxon's matched pairs test.

EDA was performed in software QCExpert 3.3 (Kupka, 2012) and the testing statistical hypotheses in Statistica 12. The significance $\alpha$ was set at 0.05, which corresponds to a $5 \%$ probability of rejecting the correct null hypothesis HO. 


\section{RESULTS}

Normal distribution of data was tested using the Kolmogorov-Smirnov, D'Agostino and the moment test. The normality was rejected in all cases at the significance level and the autocorrelation has not been proved in data. The data are dependent, since each rainfall event corresponds with the runoff from the experimental site. Due to violation of assumptions for parametric methods the Wilcoxon matched pairs test was chosen as a nonparametric alternative to the t-test for dependent (correlated) samples. The procedure assumed that the variables under consideration were measured on a scale that allows the rank ordering of observations based on each variable (i.e., ordinal scale) and that allows rank ordering of the differences between variables.

Statistical hypotheses in the context of selected methods were formulated and tested as follows. ad a) Hypothesis HO assumes that there is not statistically significant difference between the height of rainfall and runoff height on the proposed types of green roofs. P-value acquired the values of $<0.05$ in all cases, therefore the null hypothesis was rejected (Tab. 1). The test result can be interpreted so that all types of roofs have the ability to reduce the total amount of runoff.

ad b) Hypothesis HO assumes that there is not statistically significant difference between different types of roofs in the retention of rainwater. The null hypothesis was rejected in all cases in which $\mathrm{p}$-value get values $<0.05$, i.e. in all cases, except the roof type B and C (Tab. 2).

The result can be interpreted as different types of roofs proved statistically significant difference in the ability to reduce rainwater runoff, except roofs $\mathrm{B}$ and $\mathrm{C}$, which proved similar retention efficiency.

I: Wilcoxon matched pairs test-test of significant reduction of runoff using green roofs

\begin{tabular}{llll}
\hline & T & Z & p-value \\
\hline Rainfall vs. Runoff A & 0.0 & 4.86 & 0.000001 \\
Rainfall vs. Runoff B & 9.0 & 4.68 & 0.000003 \\
Rainfall vs. Runoff C & 0.0 & 4.86 & 0.000001 \\
Rainfall vs. Runoff D & 0.0 & 4.86 & 0.000001 \\
\hline
\end{tabular}

(source: authors)

II: Wilcoxon matched pairs test-test of different retention efficiency by the roof type

\begin{tabular}{lccc}
\hline & T & Z & p-value \\
\hline Runoff A vs. B & 75.0 & 3.24 & 0.001197 \\
Runoff A vs. C & 16.0 & 4.55 & 0.000005 \\
Runoff A vs. D & 105.0 & 2.62 & 0.008730 \\
Runoff B vs. C & 219.0 & 0.57 & 0.569832 \\
Runoff B vs. D & 144.0 & 2.04 & 0.041547 \\
Runoff C vs. D & 106.5 & 2.77 & 0.005556 \\
\hline
\end{tabular}

(source: authors)

\section{CONCLUSION}

The experimental green roofs were established in August 2015 and results of the research will be presented in disertation thesis of the second author of this article. Four different types of green roof plots were built so changes in water retention could be monitored. The size and the slope of each plot is the same. It was hypothesized that different types of experimental plots will result in different amount of retained water and in different quality of water runoff.

Two statistical hypotheses have been verified based on the six-month experiment consisting in monitoring runoff on different types of green roofs. The first hypothesis assessed the existence of a significant difference between the rainfall height and the height of runoff from the investigated green roofs. The significant difference was proved and it can be stated that all types of green roofs show the ability to reduce the total amount of runoff. The result of the testing of second hypothesis showed that the different types of roofs proved statistically significant differences in the ability to reduce rainwater runoff, except roofs B and C, which approved similar retention efficiency.

This experimental plots will be also used for other monitoring, as well as for educational purposes at the Department of Applied and Landscape Ecology.

\section{Acknowledgement}

The research was financially supported by the Internal Grant Agency of MENDELU project IP 39/2015 "Green roofs as an alternative way of rain water treatment". 


\section{REFERENCES}

CZECHIA. 2010. Government Regulation no. 23 of $22^{\text {nd }}$ December 2010, amending Government Regulation no. 61/2003, Coll., of indicators and values of permissible pollution of surface water and waste water, details of the permit to discharge waste water into surface water and into sewerage system, and of sensitive areas, as amended by Government Regulation no. 229/2007, Coll. In: Collection of Laws, Czech Republic. Government of the Czech Republic, no. 8, pp. 186-262. Available at: http://eagri.cz/public/web/ file/105217/sb0008_2011_23_2011.pdf

CZECHIA. 2009. Decree no. 268 of $12^{\text {th }}$ August 2009, of technical requirements for constructions. In: Collection of Laws, Czech Republic. The Ministry for Regional Development, no. 81, pp. 3702-3719. Available at: http://www.mmr.cz/getmedia/2bf72909-e837-4dc8-9488-599950e8f9f6/Vyhlaska-MMR-268-2009

CZECHIA. 2009. Decree no. 269 of $12^{\text {th }}$ August 2009, amending decree no. 501/2006, Coll., on general requirements for land use. In: Collection of Laws, CzechRepublic. The Ministry for Regional Development, no. 81, pp. 37203724. Available from: https://portal.gov.cz/app/zakony/zakon.jsp?page=0\&nr=269 2F20 09\&rpp $=15 \#$ seznam

DUNNETT, N. and KINGSBURY, N. 2004. Planting Green Roofs and Living Walls. Portland: Timber Press.

EKOEROST. 2016. List of vegetation Optigreen seeds type E. Ekrost, s.r.o.: Green roofs Optigreen [Online]. Available at: http://ekrost.cz/PDF/Osivo_E.pdf [Accessed: 2015, September 16].

GREGOIRE, B. G. and CLAUSEN, J. C. 2011. Effect of a modular extensive green roof on stormwater runoff and water quality. Ecological Engineering, 37(6): 963-969.

KUPKA,K. 2012.QC.Expert:Interactivestatisticaldata analysis [in Czech: QC.Expert:Interaktivníanalýza statistických dat]. Pardubice: TriloByte Statistical Software.

LOSKEN, G. et al. 2008. FLL (Forschungsgesellschaft Landschaftsentwicklung Landschaftsbau e.V.) - Guidelines for the Planning, Construction and Maintenance of Green Roofing - Green Roofing Guideline. $1^{\text {st }}$ Edition. Bonn.

MELOUN, M. and MILITKÝ, J. 2004. Statistical Analysis of Experimental Data [in Czech: Statistická analýza experimentálních dat]. Praha: Academia, The Academy of Sciences of the Czech Republic.

MENTENS, J., RAES, D. and HERMY, M. 2003. Greenroofs as a part of urban water management. In: BREBBIA, C. A. (Ed.). Water Resources Management II. Southampton, UK: WIT Press, pp. 35-44.

MENTENS, J.(bylo Mentend), RAES, D. and HERMY, M., 2006. Green roofs as a tool for solving the rainwater runoff problem in the urbanized $21^{\text {st }}$ century? Landscape and Urban Planning, 77: 217-226.

ISOVER. 2015. Roof-gardens ISOVER: Solution for new buildings and reconstructions. Isover. [Online]. Available at: http://www.isover.cz/data/files/stresni-zahrady-lowres-607.pdf [Accessed: 2015, October 16].

EKOEROST. 2015. Technical sheets of all Optigreen products. Ekrost, s.r.o.: Green roofs Optigreen [Online]. Available at: http://ekrost.cz/instalace.html [Accessed: 2015, October 16].

VIJAYARAGHAVAN, K. and JOSHI, U. M. 2014. Can green roof act as a sink for contaminants? A methodological study to evaluate runoff quality from green roofs. Environmental Pollution, 194: 121-129.

VIJAYARAGHAVAN, K., JOSHI, U. M. and BALASUBRAMANIAN, R. 2012. A field study to evaluate runoff quality from green roofs. Water research, 46(4): 1337-1345.

WHITE, R. 2002. Building the Ecological City. Cambridge: Woodhead Publication.

Vera Hubacikova:vera.hubacikova@mendelu.cz

Lenka Filipova: lenka.filipova@mendelu.cz

Petr Pelikan: petr.pelikan@mendelu.cz 